\title{
University-Labor Market Transition: Negative Career Thoughts and Career Adaptability
}

\author{
Liliana Faria \\ Psychology and Behavioral Sciences, Universidade Europeia, Lisbon, Portugal
}

Email: Liliana.Faria@universidadeeuropeia.pt

\begin{abstract}
The transition from the university to the labor market is a process that begins before the transition itself and continues until adaptation to the world of work. It's a phenomenon that involves planning the personal and professional future, re-evaluating current and past choices and experiences, which can lead to an ambivalence of feelings and thoughts. This article looks at the role of negative career thoughts in predicting the career adaptability. Participated 95 university students, of both sexes, who completed the negative career thoughts scale and the adaptability scale. The results indicated that the set of independent variables explained $44.9 \%$ of the variance in the control total, with all the variables of negative career thoughts having a significant influence and, $27.7 \%$ of the variance of confidence, with two of the four variables to have a single significant influence. The importance of identifying and modifying thoughts is discussed as crucial to developing a healthy career.
\end{abstract}

Keywords: Negative Career Thoughts; Career Adaptability; University-Labor Market Transition; Career Intervention.

\section{INTRODUCTION}

Rapid changes in work environments and structures, as well as the introduction of new technologies, brought the need for new and multiple career skills, namely the need to develop the career adaptability competence (Akkermans \& Tims, 2017; Akkermans et al., 2018; Plomp et al., 2016).

Career adaptability is a self-regulatory, transactional and malleable competence that allows people to successfully solve complex and illdefined problems throughout their careers (Savickas \& Porfeli, 2012). Considered a central concept in career building theory (Savickas, 2002, 2005, 2013), career adaptability has been conceptualized as a psychosocial construct to deal with various factors related to work, such as current and planned tasks, traumas associated with occupational roles and career transitions and adjustments (Savickas \& Porfeli, 2012). In this sense, it combines self-regulatory resources that people can use to deal with career requests and challenges (Savickas, 2013; Savickas \& Porfeli, 2012; Tolentino et al., 2014), and for assist in the management of work-related tasks and unexpected career changes (Chan et al., 2016; Savickas, 2005). These career adaptability features include concern, control, curiosity and Confidence, at all stages of the career (Savickas, 2005, 2013; Savickas \& Porfeli, 2012). In this way, people with high levels of career adaptability plan future career tasks (concern), take responsibility for their career development and negotiate occupational transitions (control) and, explore possible career opportunities, different roles and situations that allow to shape possible selves and alternative scenarios (curiosity). In addition, they believe in their ability to pursue career goals and aspirations, make effective career decisions and succeed in solving career-related problems (Confidence) (Savickas, 2005, 2013; Savickas \& Porfeli, 2012).

Various authors (e.g., Akkermans el al., 2018; Coetzee et al., 2015; Federici et al., 2019; Guzman \& Choi, 2013; Hartung \& Cadaret, 2017; Monteiro \& Almeida, 2015; Ohme \& Zacher, 2015; Koen et al., 2012) propose that career adaptability may be the key to solving the difficulty that newcomers to the job market have to find and keep a job satisfactorily, to deal with the uncertainty and unpredictability of new tasks, demands and restrictions, determining professional results and future career success. In addition, research has shown that career adaptability has a positive impact on academic satisfaction (Duffy et al., 2015) and job search strategies (Guzman \& Choi, 2013; Koen et al., 2010), as well as at work performance (Ohme $\&$ Zacher, 2015), commitment to work (Rossier et al., 2012), professional promotion (Chan et al., 2016), career optimism (Rudolph et al., 2017; Tolentino et al., 2014), self-esteem (Cai, et al. (2015), professional well-being (Maggiori et al., 2013) , career adaptability (Rudolph et al., 2017) and career success and satisfaction (Coetzee \& Stoltz, 2015; Chan \& Mai, 2015; Fiori et al., 2015; Guan et al., 2015). 
The mediating role of career adaptability in predicting career planning, proactive skills development and career networking (Taber \& Blankemeyer, 2015), career exploration (Li et al., 2015), career skills (Dumulescu et al., 2015), and strategic skills (Guan et al., 2016), were also proven.

Thus, taking into account the literature and the results of the research on career adaptability, it seems imperative that higher education students develop this competence, in order to enable them, not only for the university-labor market transition (Koen et al., 2010), as well as for success and career satisfaction (Coetzee \& Stoltz, 2015; Chan $\&$ Mai, 2015; Fiori et al., 2015; Guan et al., 2015).

Career literature defines the university-labor market transition as a process that begins before the transition itself and continues until adaptation to the world of work (Koivisto et al., 2007; Vieira, Caires \& Coimbra, 2011). It is a phenomenon that implies planning for the personal and professional future, reevaluating current and past choices and experiences (Koivisto et al., 2007), so it can provoke an ambivalence of feelings. Joy, on the one hand, at the end of the course and fear, apprehension and insecurity for not knowing what they will find in the future, if they will be able to put into practice everything they learned during the university, on the other (Koen et al., 2012). Thus, from our point of view, career transition and adaptability can be affected by many factors, including the presence of negative career thoughts.

In the context of the career, negative career thoughts are stated as conjectures / assumptions, beliefs and generalizations that a person maintains about himself and about the world of work, which act as cognitive barriers, and interfere in the career decision-making process and its successful development (Bullock-Yowell et al., 2012; Sampson et al., 1998; Saunders et al., 2000).

The literature (e.g., Bertoch et al., 2014) states that behavior is cognitively mediated and influenced by the interaction between cognitions, behaviors and the environment. As such, people who show pessimistic emotional, verbal and behavioral responses about their careers (Lam \& Gale, 2004), will invariably have their career decision processes affected (Sampson et al., 1998; Saunders et al., 2000), whether through the presence of confusion in decision making, commitment anxiety or conflict external (Walker \& Peterson, 2012), either, due to the difficulty / avoidance of getting involved in solving career problems (Sampson et al., 1998). Negative career thoughts influence the willingness to learn new skills, develop new interests, set career goals, make career decisions and act towards career goals (Jamali et al., 2015). These effects expand to dimensions of person satisfaction with aspects related to career progress, which may result in dissatisfaction with the person (Bullock-Yowell et al., 2011). Studies have also shown that pessimistic views on career-related issues are associated with the emergence of negative emotional states, such as anxiety and depression (Dieringer et al., 2017; Saunders et al., 2000; Walker \& Peterson, 2012), lower levels of well -being psychological, selfesteem and sense of coherence and perception of self-efficacy in career decision making (Austin et al., 2010; Lustig \& Strauser, 2002; Lustig et al., 2012; Walker \& Peterson, 2012 ), factors that can harm a person's health and performance in the development of their profession, in addition to strengthening pessimism about personal perceptions and job skills (Saunders et al., 2000), limiting career development behavior . Similarly, as demonstrated by Bullock-Yowell et al. (2011) people who have high levels of pessimism in relation to their career have higher levels of stress related to life and profession, in addition to greater dissatisfaction with the current professional choice and with work (Bullock-Yowell et al., 2012; Judge \& Locke, 1993), and low job search status (Keim et al., 2002).

\section{OBJECTIVES/AIMS OF STUDY}

This study aims to analyze the role of negative career thoughts in predicting career adaptability.

\section{METHODOLOGY}

\section{SAMPLE/PARTICIPANTS}

95 students higher education participated, of both sexes (70\% women and 30\% men), different nationalities (65\% Portuguese, $22.5 \%$ Brazilian and $12.5 \%$ Angolan) and aged between 18 and 48 years $(\mathrm{M}=26.58 ; \mathrm{SD}=8.93)$, through a convenience sampling method. Participants were enrolled in the $1 \mathrm{st}(27.5 \%)$, 2nd (52.5\%) and 3rd 
(20\%) years of different courses (55\% Psychology; $10 \%$ Communication Sciences, $10 \%$ Sports and Physical Activity Sciences, $7.5 \%$ Human Resources Management, $17.5 \%$ others).

\section{MEASURES}

Negative career thoughts were assessed using the Negative Career Thoughts Scale (Silva \& Andrade, 2016), a self-report instrument, consisting of 27 items, organized in four dimensions: Anxiety and Decision Insecurity: little confidence in career decisions ; Career Pessimism: negative thinking that comes from fear of failure and lack of confidence; Market pessimism: negative thoughts regarding past experiences and professional value; and Cost for success: negative thoughts about the costs necessary to achieve success. The answer to each item is given through a five-point Likert scale ( $1=$ I don't identify myself at all and $5=$ I identify myself completely). The scale presents reliability indexes that vary between .78 and .91 .

Career adaptability was assessed using the Adaptability Scale (Duarte et al., 2012), a selfreport instrument, consisting of 28 items, organized in four dimensions: Concern: orientation for the future and the development of skills to plan; Control: responsibility for building your own career and being able to make decisions; Curiosity: attitude that leads you to explore the environment to learn more about yourself and situations; and Confidence: ability to solve a problem or successfully perform a certain action. The answer to each item is given using a five-point Likert scale ( 1 = very little; $5=$ a lot $)$. Previous studies carried out with higher education students indicate reliability coefficients of .90 [subscales: concern (.76), control (.69), curiosity (.78) and confidence (.79)] (Duarte et al., 2012).

\section{DATA COLLECTION ANALYSIS PROCEDURES}

AND

For data collection, the survey was carried out by means of a questionnaire on the Google Forms platform, consisting of the measures previously presented, to which was added the description of the study objective and a free and informed consent. The survey was disseminated through facebook, through the sharing of several people, all of them higher education students. It is not required to submit to the Ethics Committee, as it is not a required pattern in Portugal.
The analysis of the exported data was based on the statistical analysis tool IBM SPSS 22.0, which consisted of descriptive statistics analysis for the sociodemographic characterization of the participants, Cronbach's Alpha calculations, through the measurement of the internal consistency of the scales used, in order to evaluate its reliability, as well as inferential statistical analyzes, namely Pearson's t tests and correlations, and multiple regression analysis. The level of statistical significance adopted in the analyzes was $5 \%(\mathrm{p}<.05)$.

Multiple linear regression was used to obtain a parsimonious model that would allow analyzing the impact of negative career thoughts on career adaptability. The model's assumptions were analyzed, namely that of normal distribution (Kolmogorov-Smirnov and Shapiro-Wilk with $\mathrm{p}>$ $.05)$, homogeneity and independence of errors (Tabachnick \& Fidell, 2001). The first two assumptions were validated graphically and the independence assumption was validated with the Durbin-Watson statistic $(\mathrm{d}=2.31)$ as described by Maroco (2007). The Variance Inflation Factor and Tolerance were used to diagnose multicollinearity (all VIF values were less than 1.475; all Tolerance values were around 1.00) and the analysis of Standardized Residual and Cook's D to ascertain the absence of outliers (Standardized Residual varies between -2.5 and 2.8, Cook's D =.039).

\section{RESULTS}

Table 1 shows the mean and standard deviation for the subscales of career adaptability and negative career thoughts, as well as the statistically significant differences for these variables, according to sex.

The values in career adaptability oscillate between those obtained in the Concerns and Curiosity subscales $(M=3.96)$ and those reached in the Confidence subscale $(\mathrm{M}=4.09)$. In turn, negative career thinking levels fluctuate between the values obtained in the Career Pessimism ( $\mathrm{M}=$ 1.63) and Market Pessimism $(\mathrm{M}=2.90)$ subscale. It was also found that the results are above the midpoint in all subscales of career adaptability, either in the total sample or in the samples of boys and girls, and below the midpoint in all subscales of PNC, or in total sample, either in the boys and girls samples. There is only a statistically significant difference in terms of Market Pessimism $(t=.225 ; \mathrm{p}<.05)$, favorable to girls. 
Table 1: Career Adaptability and Negative Career Thoughts by Gender

\begin{tabular}{|llllllll|}
\hline Subscales & \multicolumn{2}{c}{ Total } & \multicolumn{2}{c}{ Women } & \multicolumn{2}{c}{ Men } & T \\
Concern & Mean & SD & Mean & SD & Mean & SD & -2.089 \\
Control & 3.96 & 0.54 & 3.85 & 0.53 & 4.23 & 0.48 & -.638 \\
Curiosity & 4.05 & 0.52 & 4.02 & 0.45 & 4.13 & 0.67 & .267 \\
Confidence & 3.96 & 0.55 & 3.98 & 0.54 & 3.93 & 0.59 & -.989 \\
Anxiety and Decision Insecurity & 4.09 & 0.57 & 4.03 & 0.54 & 4.23 & 0.65 & -.531 \\
Career Pessimism & 2.40 & 0.97 & 2.35 & 0.96 & 2.53 & 1.02 & .677 \\
Market Pessimism & 1.63 & 0.73 & 1.69 & 0.76 & 1.51 & 0.67 & $.226^{*}$ \\
Costs for Success & 2.90 & 0.74 & 2.92 & 0.93 & 2.85 & 0.59 & -.380 \\
Concern & 2.59 & 1.08 & 2.545 & 1.13 & 2.69 & 0.98 & -2.089 \\
\hline *p $<.05$ & & & & & & &
\end{tabular}

Table 2 shows the reliability analyzes of the different subscales using Cronbach's Alpha coefficient, as well as the linear correlations between the variables. The level of reliability of the different subscales of career adaptability and negative career thoughts, present Cronbach's Alpha values greater than 70 , thus ensuring a good internal consistency of the items. The presence of a moderate negative correlation (.30-.50) between the Anxiety and Decision Insecurity subscale and the career adaptability subscales Concern $(r=-$
$.376 ; \mathrm{p}<.05)$, Control $(\mathrm{r}=-.533 ; \mathrm{p}<.01)$, Curiosity $(\mathrm{r}=-.361 ; \mathrm{p}<.05)$, and Confidence $(\mathrm{r}=-.445 ; \mathrm{p}<$ $.01)$; Career pessimism and the subscales of adaptability Control $(\mathrm{r}=-.596 ; \mathrm{p}<.01)$, Curiosity $(\mathrm{r}=-.403 ; \mathrm{p}<.05)$, and Confidence $(\mathrm{r}=-.383 ; \mathrm{p}<$ $.01)$; Costs for Success and the Adaptability Confidence subscale $(\mathrm{r}=-.352 ; \mathrm{p}<.05)$. The Market Pessimism subscale is not statistically significantly associated with any of the adaptability subscales.

Table 2: Reliability and Inter-Correlation Between Variables

\begin{tabular}{|c|c|c|c|c|c|c|c|c|c|c|}
\hline & Items & Alpha & 1 & 2 & 3 & 4 & 5 & 6 & 7 & 8 \\
\hline 1. Concern & 7 & .779 & & $.604 * *$ & $.645^{* *}$ & $.537 * *$ & $-.376^{*}$ & -.285 & -.298 & -.182 \\
\hline 2. Control & 7 & .773 & & & $.679 * *$ & $.684 * *$ & $-.533 * *$ & $-.596 * *$ & -.151 & -.245 \\
\hline 3. Curiosity & 7 & .790 & & & & $.582 * *$ & $-.361 *$ & $-.403 *$ & -.212 & -.262 \\
\hline 4. Confidence & 7 & .840 & & & & & $-.445 * *$ & $-.383^{*}$ & -.168 & $-.352^{*}$ \\
\hline $\begin{array}{l}\text { 5. Anxiety and } \\
\text { Decision } \\
\text { Insecurity }\end{array}$ & 9 & .912 & & & & & & $.559 * *$ & $.510 * *$ & .244 \\
\hline $\begin{array}{l}\text { 6. Career } \\
\text { Pessimism }\end{array}$ & 6 & .850 & & & & & & & $.352 *$ & .130 \\
\hline $\begin{array}{l}\text { 7. Market } \\
\text { Pessimism }\end{array}$ & 8 & .785 & & & & & & & & $.554 * *$ \\
\hline $\begin{array}{l}\text { 8. Costs for } \\
\text { Success }\end{array}$ & 4 & .831 & & & & & & & & \\
\hline
\end{tabular}

In order to further study the influence of negative career thoughts on career adaptability, we use four multiple regressions of ordinary least squares to determine whether negative career thoughts have a primary influence on adaptability variables and, if so, which subscales of negative career thoughts represents the greatest variance. The independent variables were the four subscales of negative career thoughts and the dependent variables were the four adaptability subscales as shown in Table 3. 
Table 3: Summary of Regression Analyzes of Negative Career Thoughts as Predictors of Career Adaptability

\begin{tabular}{|lllllll}
\hline Variable & R2 & R2a & B & Beta & t & Sig \\
Concern & .164 & .069 & & & & \\
Anxiety and Decision Insecurity & & & -.111 & -.254 & -1.250 & .220 \\
Career Pessimism & & & -.080 & -.098 & -.524 & .604 \\
Market Pessimism & & -.062 & -.108 & -.512 & .612 \\
Costs for Success & & & -.041 & -.047 & -.252 & .802 \\
Control & $.506^{* *}$ & $.449 * *$ & & & & \\
Anxiety and Decision Insecurity & & & -.163 & -.389 & -2.483 & .018 \\
Career Pessimism & & & -.397 & -.474 & -3.283 & .002 \\
Market Pessimism & & & .208 & .379 & 2.340 & .025 \\
Costs for Success & & & -.253 & -.298 & -2.083 & .045 \\
Curiosity & & & & & \\
Anxiety and Decision Insecurity & & & -.086 & -.196 & -1.002 & .323 \\
Career Pessimism & & & -.271 & -.308 & -1.711 & .096 \\
Market Pessimism & & & .077 & .133 & .659 & .514 \\
Costs for Success & & & -.221 & -.248 & -1.387 & .174 \\
Confidence & & & -.387 & -.416 & -2.533 & .016 \\
Anxiety and Decision Insecurity & & & -.179 & -.388 & -2.159 & .038 \\
Career Pessimism & & & -.215 & -.233 & -1.409 & .168 \\
Market Pessimism & & & & & & \\
Costs for Success & & & & & & \\
\hline
\end{tabular}

The regression results indicated that the set of independent variables explained $44.9 \%$ of the variance in the total of Control, with all variables of negative career thoughts having a significant influence: (a) Anxiety and Decision Insecurity $(\beta=$ -.389), (b) Career Pessimism ( $\beta=-.474)$, (c) Market Pessimism $(\beta=.379)$ and, $(d)$ Costs for Success $(\beta=-.298)$. The results also indicated that the set of independent variables explained $27.7 \%$ of the confidence variance, with two of the four variables having a single significant influence: (a) Anxiety and Decision Insecurity $(\beta=-.388)$ and (b) Costs for Success $(\beta=-.416)$.

\section{CONCLUSION}

This study examined the impact of negative career thinking on career adaptability in a sample of university students. Overall, the data support the hypothesis that negative career thoughts negatively impact career adaptability.

In view of the results of the statistical analyzes presented in this work, the evidence shows that the measures of negative career thoughts and career adaptability are powerful measures to study negative career thoughts and career adaptability, respectively, since the results obtained in in terms of reliability, they are highly satisfactory (Maroco, 2007; Tabachnick \& Fidell, 2001). Similar results with Portuguese samples were obtained by Duarte and collaborators (2012) and Monteiro and Almeida (2015) for the adaptability scale and, with Brazilian samples by Silva (2016) and Silva and Andrade (2016) for the career negative thoughts scale. 
The statistical analysis highlighted that all the dimensions of adaptability show high averages, of approximately 4, which shows that the participants seem to have high resources for career adaptability, especially confidence and control. That is, they seem to believe in their ability to pursue career goals and aspirations, make effective career decisions and succeed in solving career-related problems (confidence), as well as taking responsibility for the development of their careers and negotiating occupational transitions (control) (Savickas, 2005, 2013; Savickas \& Porfeli, 2012). The results related to the differential study based on sex are in line with the study by Rossier et al. (2012), which shows that career adaptability is not related to sex. Regarding negative career thoughts, descriptive analysis reveals that all dimensions of negative career thoughts show low averages, of approximately $2 / 3$, which shows that participants seem to have low negative career thoughts. Differential studies show that girls tend to be more pessimistic about the market than boys. In other words, girls seem to have more negative thoughts about experiences with the job market, reflecting anxieties and fears about the possibility of not having the expected return on investments made in their careers, of not finding opportunities for growth or of not being valued as a professional (Silva \& Andrade, 2016).

Although no causality can be inferred from our data, the results of inter-correlations demonstrate that: (i) as thoughts of anxiety and decision insecurity increase, the dimensions of career adaptability, concern, control, curiosity and confidence decrease; (ii) the more students are pessimistic about their careers, the less control, curiosity and confidence they have; (iii) more negative thoughts regarding the costs of success are associated with lower levels of confidence. These results demonstrate that typically, individuals with latent schemes related to negative cognitions can activate them when they have to solve career problems and make career decisions, reinforcing their pessimistic views about themselves and about the work world, present and future (BullockYowell et al. 2011; Dieringer et al., 2017), reducing opportunities to explore identities, social roles and interests that contact with the workplace promotes (Akkermans at al., 2018; Cai et al 2015; Savickas \& Porfeli , 2012).
The results also indicate that the four dimensions of negative career thoughts were responsible for a significant portion of the variation of two adaptability, control and confidence resources, supporting the hypothesis that negative career thoughts negatively impact career adaptability. . That is, less negative career thoughts seem to be associated with greater levels of control and confidence in the career. We speculate that, conversely, individuals with higher levels of negative career thinking have lower career adaptability resources (Sampson et al., 1998; Savickas, 2005, 2013; Savickas \& Porfeli, 2012). More specifically, the results seem to indicate that, in particular, lower levels of anxiety and decision insecurity regarding the decision are related to the ability to set goals, make career decisions and solve problems related to the career and, consequently, to assume the responsibility of the career (Savickas, 2005, 2013; Savickas \& Porfeli, 2012). One possible explanation for this result is that individuals involved in personal growth activities may experience associated anxiety about their future career plans because of their ongoing attempts to incorporate newly developed skills into current and future academic and research endeavors career (Lustig et al., 2012).

\section{LIMITATIONS \& SUGGESTION/ RECOMMENDATIONS}

The generalization of our results is limited for the following reasons. First, the convenience sample (not probabilistic) was composed of 95 university students and there is a large gap in the number of different genders of the participants, therefore, this sample is not representative of the population, so the interpretation of results should be limited to the sample used in the study. Second, given the non-experimental and cross-sectional nature of the study design, causal relationships between variables cannot be made. Third, the measures used in the study were self-report measures, susceptible to social desirability, because they can influence the results of the study. Fourth, multiple linear regression was used for the analysis, however, the use of Structural Equation modeling might have given a more plausible causality in the relationship between the predictors and the dependent variable. However, the choice of 
multiple linear regression for analysis was because the objective of the study was simply to understand the basic relationship between the predictor variable (negative career thoughts) and the dependent variable (adaptability) (Maroco, 2007).

For the reasons presented above, it is suggested that future studies be conducted with representative and significant samples, in order to be able to make generalizations for the population of university students and, use the structural equation model to analyze the causal relationship between the predictors and the result variables in order to obtain more plausible results. In addition, students' career adaptability skills, developed while attending higher education career, may not be maintained after graduation, so follow-up studies should also be developed.

The results of the study also allow us to draw some implications for the practice, at a social, school and individual level. At the social level, the need to greater training of young people to reflect on issues in the world of work, in order to avoid and prevent negative and unrealistic thoughts related to their careers. Likewise, it is important to defend the perspective that adaptation is a dynamic, permanent process, with multiple interactions between environments and individuals and should be considered around the nature of these interactions and, as such, consider the possibility of work environments adopt a more humanistic vision, and individuals build themselves as adaptable workers, and do not become adapted workers, only adjusted to their job or function, in their choices and worker attitudes. In turn, at school level it is important to be aware that decent work, career education, and the processes of building knowledge and developing specific career attitudes and career skills that enable life to be managed school, professional and personal in a constructive, assertive and ethically contextualized way, in the groups, institutions and society where they live or want to live, they do not happen through education, they require other types of activities and experiences. Thus, the work of psychologists and career psychology specialists in the field becomes important (Koen et al., 2012). Finally, at an individual level, exercises to encourage the establishment of personal goals, situations for exploring yourself and the environment, are recommended. In addition, activities aimed at the cognitive restructuring of negative thoughts associated with the career (identification, challenge and alteration of negative thoughts), taking into account the different socio-economic and cultural contexts, followed by behavioral interventions to help clients act according to their own needs new thoughts will also be fundamental (Savickas \& Porfeli, 2012). Modifying negative reasoning about careers can improve affective and cognitive functioning and, of course, allow students to effectively advance them in the challenges associated with their careers.

\section{REFERENCES}

[1] Akkermans J., \& Tims M. (2017). Crafting your career: how career competencies relate to career success via job crafting. Applied Psychology, 66(1), 168-195. https://doi.org/10.1111/apps.12082

[2] Akkermans, J., Paradniké, K., Van der Heijden, B., \& De Vos, A. (2018). The best of both worlds: the role of career adaptability and career competencies in students' well-being and performance. Frontiers in Pychology, 9, 1678. https://doi.org/10.3389/fpsyg.2018.01678

[3] Austin, R. K, Dahl, A., \& Wagner, B. (2010). The roles of negative career thoughts and sense of coherence in predicting career decision status. Canadian Journal of Counselling and Psychotherapy, 44(1), 65-77. Retrieved from https://cjc-rcc.ucalgary.ca/article/view/58798

[4] Bertoch, S., Lenz, J., Reardon, R., \& Peterson, G. (2014). Goal instability in career thoughts, decision state, and performance in a career course. Journal of Career Development, 41(2), 104-121. https://doi.org/10.1177/0894845313482521

[5] Bullock-Yowell, E., Katz, S. P., Reardon, R. C., \& Peterson, G. W. (2012). The roles of negative career thinking and career problem-solving self-efficacy in career exploratory behavior. The Professional Counselor, 2(2), 102-104. https://doi.org/10.15241/sll.2.2.115

[6] Bullock-Yowell, E., Peterson, G., Reardon, R., Leierer, S., \& Reed, C. (2011). Relationships among career and life stress, negative career thoughts, and career decision state: A cognitive information processing perspective. Career Development Quarterly, 59(4), 302-314. https://doi.org/10.1002/j.2161-0045.2011.tb00071.x

[7] Cai, Z., Guan, Y., Li, H., Shi, W., Guo, K., Liu, Y., et al. (2015). Self-esteem and proactive personality as predictors of future work self and career adaptability: An examination of mediating and moderating processes. Journal of Vocational Behavior, 86, 86-94. https://doi.org/10.1016/j.jvb.2014.10.004 
[8] Chan, S. H. J., \& Mai, X. (2015). The relation of career adaptability to satisfaction and turnover intentions. Journal of Vocational Behavior, 89, 130-139. https://doi.org/10.1016/j.jvb.2015.05.005

[9] Chan, S. H. J., Mai, X., Kuok, O. M. K., \& Kong, S. H. (2016). The influence of satisfaction and promotability on the relation between career adaptability and turnover intentions. Journal of Vocational Behavior, 92, 167175. https://doi.org/10.1016/j.jvb.2015.12.003

[10] Coetzee, M., \& Stoltz, E. (2015). Employees' satisfaction with retention factors: Exploring the role of career adaptability. Journal of Vocational Behavior, 89, 83-91. https://doi.org/10.1016/j.jvb.2015.04.012

[11] Coetzee, M., Ferreira, N., \& Potgieter, I. L. (2015). Assessing employability capacities and career adaptability in a sample of human resource professionals. SA Journal of Human Resource Management, 13(1), 1-9. https://doi.org/10.4102/sajhrm.v13i1.682

[12] Dieringer, D. D., Lenz, J. G., Hayden, S. C. W., \& Peterson, G. W. (2017). The relation of negative career thoughts to depression and hopelessness. The Career Development Quarterly, 65(2), 159-172. https://doi.org/10.1002/cdq.12089

[13] Duarte, M. E., Soares, M. C., Fraga, S., Rafael, M., Lima, M. R., Paredes, I., Agostinho, R., \& Djaló, A. (2012). Career adaptability scale-Portugal form: psychometric properties and relationships to employment status. Journal of Vocational Behavior, 80(3), 725-729. https://doi.org/10.1016/j.jvb.2012.01.019

[14] Duffy, R. D., Douglass, R. P., \& Autin, K. L. (2015). Career adaptability and academic satisfaction: Examining work volition and self-efficacy as mediators. Journal of Vocational Behavior, 90, 46-54.

https://doi.org/10.1016/j.jvb.2015.07.007

[15] Dumulescu, D., Balazsi, R., \& Opre, A. (2015). Calling and career competencies among Romanian students: The mediating role of career adaptability. Procedia-Social and Behavioral Sciences, 209, 25-32. https://doi.org/10.1016/j.sbspro.2015.11.223

[16] Federici, E., Boon, C., \& Den Hartog, D. N. (2021). The moderating role of HR practices on the career adaptability-job crafting relationship: a study among employee-manager dyads. The International Journal of Human Resource Management, 32(6), 1339-1367. https://doi.org/10.1080/09585192.2018.1522656

[17] Fiori, M., Bollmann, G., \& Rossier, J. (2015). Exploring the path through which career adaptability increases job satisfaction and lowers job stress: The role of affect. Journal of Vocational Behavior, 91, 113-121. https://doi.org/10.1016/j.jvb.2015.08.010

[18] Guan, Y., Yang, W., Zhou, X., Tian, Z., \& Eves, A. (2016). Predicting Chinese human resource managers' strategic competence: Roles of identity, career variety, organizational support and career adaptability. Journal of Vocational Behavior, 99, 116-124. https://doi.org/10.1016/j.jvb.2015.11.012

[19] Guan, Y., Zhou, W., Ye, L., Jiang, P., \& Zhou, Y. (2015). Perceived organizational career management and career adaptability as predictors of success and turnover intention among Chinese employees. Journal of Vocational Behavior, 88, 230-237. https://doi.org/10.1016/j.jvb.2015.04.002

[20] Guzman, A. B., \& Choi, K. O. (2013). The relations of employability skills to career adaptability among technical school students. Journal of Vocational Behavior, 82(3), 199-207.

https://doi.org/10.1016/j.jvb.2013.01.009

[21] Hartung, P. J., \& Cadaret, M. C. (2017). Career adaptability: Changing self and situation for satisfaction and success. In K. Maree (Ed.), Psychology of career adaptability, employability and resilience (pp. 1528). Springer. https://doi.org/10.1007/978-3-319-66954-0_2

[22] Jamali, Y., Araqi, V., \& Kalantarkousheh, S. M. (2015). Function of dysfunctional career thoughts, procrastination and career indecision among Allameh Tabatab'i University students. European Online Journal of Natural and Social Sciences, 4(1), 57-65.

[23] Judge, T. A., \& Locke, E. A. (1993). Effect of dysfunctional thought processes on subjective well-being and job satisfaction. Journal of Applied Psychology, 78(3), 475-490. https://doi.org/10.1037/0021-9010.78.3.475

[24] Keim, J., Strauser, D.R., \& Ketz, K. (2002). Examining the differences in career thoughts of women in three low socio economics status groups. Journal Employment Counseling, 39(1), 31-43.

https://doi.org/10.1002/j.2161-1920.2002.tb00506.x

[25] Koen, J., Klehe, U. C., \& Van Vianen, A. E.M. (2012). Training career adaptability to facilitate a successful school-to-work transition. Journal of Vocational Behavior, 81(3), 395-408.

https://doi.org/10.1016/j.jvb.2012.10.003

[26] Koen, J., Klehe, U. C., Van Vianen, A. E., Zikic, J., \& Nauta, A. (2010). Job-search strategies and reemployment quality: The impact of career adaptability. Journal of Vocational Behavior, 77(1), 126-139. https://doi.org/10.1016/j.jvb.2010.02.004

[27] Koivisto, P., Vuori, J. \& Nykyri, E. (2007). Effects of the school-to-work group method among young people. Journal of Vocational Behavior, 70(2), 277-296. https://doi.org/10.1016/j.jvb.2006.12.001 
[28] Lam, D., \& Gale, J. (2004). Cognitive behaviour therapy: An evidence based clinical framework for working with dysfunctional thoughts. Counselling Psychology Quarterly, 17(1), 53-67. https://doi.org/10.1080/09515070410001665884

[29] Li, Y., Guan, Y., Wang, F., Zhou, X., Guo, K., Jiang, P., Mo, Z., Li, Y., \& Fang, Z. (2015). Big-five personality and BIS/BAS traits as predictors of career exploration: The mediation role of career adaptability. Journal of Vocational Behavior, 89, 39-45. https://doi.org/10.1016/j.jvb.2015.04.006

[30] Lustig, D. C., \& Strauser, D. R. (2002). The relationship between sense of coherence and career thoughts. Career Development Quarterly, 51(1), 2-11. https://doi.org/10.1002/j.2161-0045.2002.tb00587.x

[31] Lustig, D. C., Zanskas, S., \& Strauser, D. R. (2012). The relationship between psychological distress and career thoughts. Journal of Rehabilitation, 78(4), 3-10.

[32] Maggiori, C., Johnston, C.S., Krings, F., Massoudi, K., \& Rossier, J. (2013). The role of career adaptability and work conditions on general and professional well-being. Journal of Vocational Behavior, 83(3), 437-449. https://doi.org/10.1016/j.jvb.2013.07.001

[33] Maroco, J. (2007). Análise Estatística com utilização do SPSS. Edições Sílabo.

[34] Monteiro, S., \& Almeida, L. S. (2015). The relation of career adaptability to work experience, extracurricular activities, and work transition in Portuguese graduate students. Journal of Vocational Behavior, 91, 106-112. https://doi.org/10.1016/j.jvb.2015.09.006

[35] Ohme, M., \& Zacher, H. (2015). Job performance ratings: The relative importance of mental ability, conscientiousness, and career adaptability. Journal of Vocational Behavior, 87, 161-170.

https://doi.org/10.1016/j.jvb.2015.01.003

[36] Plomp, J., Tims, M., Akkermans, T. J., Khapova, S. N., Jansen, P. G., \& Bakker, A. B. (2016). Career competencies and job crafting: How proactive employees influence their well-being. Career Development International, 21(6), 587-602. https://doi.org/10.1108/CDI-08-2016-0145

[37] Rossier, J., Zecca, G., Stauffer, S. D., Maggiori, C., \& Dauwalder, L. Jean-Pierre (2012). Career adaptabilities scale in a French-speaking Swiss sample: Psychometric properties and relationships to personality and work engagement. Journal of Vocational Behavior, 80(3), 734-743. https://doi.org/10.1016/j.jvb.2012.01.004

[38] Rudolph, C., Lavigne, K. \& Zacher, H. (2017). Career adaptability: A meta-analysis of relationships with measures of adaptivity, adapting responses, and adaptation results. Journal of Vocational Behavior, 98, 17-34. https://doi.org/10.1016/j.jvb.2016.09.002

[39] Sampson, J. P., Peterson, G. W., Lenz, J. G., Reardon, R. C., \& Saunders, D. E. (1998). The design and use of a measure of dysfunctional career thoughts among adults, college students, and high school students: the career thoughts inventory. Journal of Career Assessment, 6(2), 115-134.

https://doi.org/10.1177/106907279800600201

[40] Saunders, D., Peterson, G., Sampson, J., \& Reardon, R. (2000). Relation of depression and dysfunctional career thinking to career indecision. Journal of Vocational Behavior, 56(2), 288-298.

https://doi.org/10.1006/jvbe.1999.1715

[41] Savickas, M. L. (2002). Career construction: A developmental theory of vocational behavior. In D. Brown (Ed.), Career choice and development (pp. 255-311) (4th Ed.). Jossey-Bass.

[42] Savickas, M. L. (2005). The theory and practice of career construction. In R.W. Lent, \& S.D. Brown (Eds.), Career development and counseling: Putting theory and research to work (pp. 42-70). John Wiley \& Sons.

[43] Savickas, M. L. (2013). Career construction theory and practice. In R.W. Lent, \& S.D. Brown (Eds.), Career development and counseling: Putting theory and research to work (pp. 14-183) (2nd ed.). John Wiley \& Sons.

[44] Savickas, M. L., \& Porfeli, E. J. (2012). Career Adaptabilities Scale: Construction, reliability, and measurement equivalence across 13 countries. Journal of Vocational Behavior, 80, 661-673. https://doi.org/10.1016/j.jvb.2012.01.011

[45] Silva, M., \& Andrade, A. L. (2016). Avaliando pensamentos negativos sobre a carreira: o desenvolvimento de uma medida (EPNC). Revista Brasileira de Orientação Profissional, 17(2), 175-187.

[46] Silva, M. (2016). Pensamentos negativos de carreira e aspectos psicológicos relacionados à satisfação com os resultados alcançados na vida e na carreira. Dissertação de mestrado. Universidade Federal do Espírito Santo.

[47] Tabachnick, B. G., \& Fidell, L. S. (2001). Using Multivariate Statistics. Allyn and Bacon.

[48] Taber, B. J., \& Blankemeyer, M. (2015). Future work self and career adaptability in the prediction of proactive career behaviors. Journal of Vocational Behavior, 86, 20-27. https://doi.org/10.1016/j.jvb.2014.10.005

[49] Tolentino, L. R., Garcia, P. R., Lu, V. N., Restubog, S. L., Bordia, P., \& Plewa, C. (2014). Career adaptation: The relation of adaptability to goal orientation, proactive personality, and career optimism. Journal of Vocational Behavior, 84(1), 39-48. https://doi.org/10.1016/j.jvb.2013.11.004 
[50] Vieira, D., Caires, S., \& Coimbra, J. L (2011). Do ensino superior para o trabalho: Contributo dos estágios para inserção profissional. Revista Brasileira de Orientação Profissional, 12(1), 29-36.

[51] Walker, J., \& Peterson, G. (2012). Career thoughts, indecision and depression: Implications for mental health assessment in career counseling. Journal of Career Assessment, 20(4), 497-506. https://doi.org/10.1177/1069072712450010

Received on 12-10-2021

Accepted on 06-11-2021

Published on 18-11-2021

(C) 2021 Liliana Faria; Licensee ATSK Publishers.

This is an open access article licensed under the terms of the Creative Commons Attribution Non-Commercial License (http://creativecommons.org/licenses/by-nc/3.0/) which permits unrestricted, noncommercial use, distribution and reproduction in any medium, provided the work is properly cited. 